\title{
Sistem Informasi Geografis Pencarian Rute Optimum Lokasi Obyek Wisata Kota Semarang Menggunakan Algoritma Dijkstra
}

\author{
Bambang Agus Herlambang ${ }^{1}$, Septio Oggy Pradana², Rahmat Robi Waliyansyah³ \\ 1 Program Studi Informatika, Fakultas Teknik dan Informatika, Universitas PGRI \\ Semarang \\ 2 Program Studi Informatika, Fakultas Teknik dan Informatika, Universitas PGRI \\ Semarang \\ 3 Program Studi Informatika, Fakultas Teknik dan Informatika, Universitas PGRI \\ Semarang
}

\begin{abstract}
The Semarang City Government is currently developing tourism potential in the Semarang City area. However, the number of tourist attractions in the city of Semarang makes tourists who come to the city of Semarang to be confused to visit the tourist attractions that will be visited. In this study the authors provide solutions for grouping based on the type of tour such as religious tourism, environmental tourism, water tourism, nature tourism and education tourism. The use of the Dijkstra algorithm will be used to help find solutions to visit these tourist attractions. In this system the Google Maps API will be used to display spatial data to indicate the route to be passed. System design to create a Geographic Information System using the Unified Modeling Language (UML). Tourists later use this application by entering the initial location information and the location you want to get to get the route. Based on testing that has been done the system is able to display information on the route it travels will be bypassed by tourists. The results of research and field studies that have been carried out, can be concluded from the user acceptance testing in terms of usefulness of $89.5 \%$, in terms of use of $89.3 \%$, in terms of appearance of $89.5 \%$, and in terms of accuracy of $87.6 \%$, that is strongly agree.
\end{abstract}

Keywords: Geographic Information System, Tourism Object, Optimum Route, Dijkstra's Algorithm

corresponding email :

rahmat.robi.waliyansyah@upgris.ac.id

This is an open access article under the $\underline{C C B Y}$ license

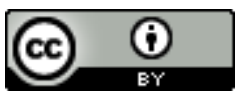

\section{INTRODUCTION}

Perkembangan teknologi saat ini mampu merubah pola hidup seseorang dengan pengenalan berbagai teknologi yang berkembang di berbagai bidang [1]. Penemuan teknologi terbaru muncul di berbagai Negara dan dijadikan sebagai tanda negara itu mampu menerima sebuah teknologi atau belum siap untuk menerima perkembangan teknologi [2]. Perkembangan teknologi itu ditandai dengan munculnya produk-produk yang ada di dalam negara itu di berbagai bidang. Salah satunya adalah dibidang informatika yaitu Sistem Informasi Geografis [3].

Sistem Informasi Geografis merupakan sistem informasi yang didalamnya berisi informasi penting terkait tempat yang bersifat khusus agar pengguna mampu membaca sistem informasi tersebut dengan mudah [4]. Pembuatan Sistem Informasi Geografis natinya akan memudahkan pengguna untuk melihat suatu lokasi secara detail [5]. Dengan adanya teknologi ini, maka akan memudahkan sesorang untuk mendapatkan posisi tempat wisata yang berada di Kota Semarang [6].

Banyaknya obyek wisata di Kota Semarang menjadikan wisatawan yang berkunjung merasa bimbang untuk memilih lokasi obyek wisata yang berada di Kota Semarang. Dari data hasil survey lapangan dan data dinas pariwisata Kota Semarang didapatkan jumlah objek wisata yang dibagi menjadi delapan kategori wisata mulai dari wisata religi, lingkungan, budaya, air, alam, desa, pendidikan \& belanja [6]. Dengan banyaknya rute menuju tempat wisata di Kota Semarang, wisatawan akan memilih rute optimum untuk menuju ke lokasi obyek wisata. 
JAST : Journal of Applied Science and Technology

Volume. 02 Number. 01, January 2022

ISSN : 2775-4022

http://jurnal.unissula.ac.id/index.php/JAST

Untuk menentukan rute optimum, maka penulis akan menggunakan metode Dijkstra untuk menentukan rute terdekat antara pengguna dengan tempat tujuan lokasi obyek wisata. Dijkstra adalah satu di antara beberapa algoritma yang efektif pada saat menentukan jarak terpendek dari satu tempat ke tempat yang lain [7]. Prinsip dasar dari algoritma Dijkstra yaitu dengan mencari jarak lintasan yang terkecil [8]. Algoritma tersebut mempunyai perulangan untuk mendapatkan rute yang jangkauannya dari posisi awal menuju posisi akhir yaitu terpendek [9].

Dari uraian di atas bisa diambil suatu kesimpulan dimana Sistem Informasi Geografis ini sangat membantu sekali dalam pencarian tempat wisata yang berada di Kota Semarang. Tujuan dari riset ini yaitu untuk memberikan review informasi lokasi obyek wisata Kota Semarang \& menginformasi letak obyek wisata di Kota Semarang dengan menggunakan rute optimum.

Berikut ini adalah beberapa penelitian terkait dengan pemnfaatan SIG dalam sektor pariwisata. Prasetyo et al., (2018) membuat aplikasi untuk mencari lokasi objek wisata kuliner dengan menggunakan SIG berbasi website di Kota Mataram [10]. Aplikasi tersebut bisa memperlihatkan data tempat lokasi wisata kuliner yang berdasarkan kategori radius lokasi kuliner \& menu yang dipilih oleh pengguna.

Selanjutnya penelitian yang dilakukan oleh Kusuma \& Budisusanto (2015) membuat SIG pariwisata berbasis web dengan memanfaatkan aplikasi Google Maps API [11]. Kabupaten Sidoarjo merupakan tempat studi kasus yang dipilih. Hasil penelitian ini yaitu WebGIS yang bisa menampilkan informasi pariwisata dengan tampilan peta terrain \& satelit yang ditambahkan fitur untuk menambahkan lokasi, memberi penilaian terhadap tampilan web, melengkapi informasi \& mencari objek wisata. Kuisioner yang digunakan memiliki penilaian khusus yaitu uji kebergunaan yang meliputi lima komponen yaitu efficiency, learnability, errors, satisfaction \& memorability. Hasil dari kuisioner menggunakan 25 responden dengan waktu penayangan berkisar 17 - 10 November 2014 yang memberikan peresentase yaitu 70,69\% sehingga website tersebut masuk kategori layak.

\section{LITERATURE REVIEW}

a. Sistem Informasi Geografis

Di era globalisasi dan era informasi seperti sekarang ini, banyak hal yang bisa dijadikan sebagai alat bantu atau sebagai media untuk pencarian suatu lokasi atau penuntun arah ke suatu lokasi. Di antaranya menggunakan Teknologi Informasi khususnya Sistem Informasi Geografis (SIG) atau Geographic Information Systems (GIS). Sistem Informasi Georafis atau Geographic Information System (GIS) merupakan suatu sistem informasi yang berbasis komputer, dirancang untuk bekerja dengan menggunakan data yang memiliki informasi spasial (bereferensi keruangan). Sistem Informasi Geografis (SIG) di definisikan sebagai kumpulan yang terorganisir dari perangkat keras computer, perangkat lunak, data geografi dan personil yang didesain untuk memperoleh, menyimpan, memperbaiki, memanipulasi, menganalisis dan menampilkan semua bentuk informasi yang bereferensi geografis

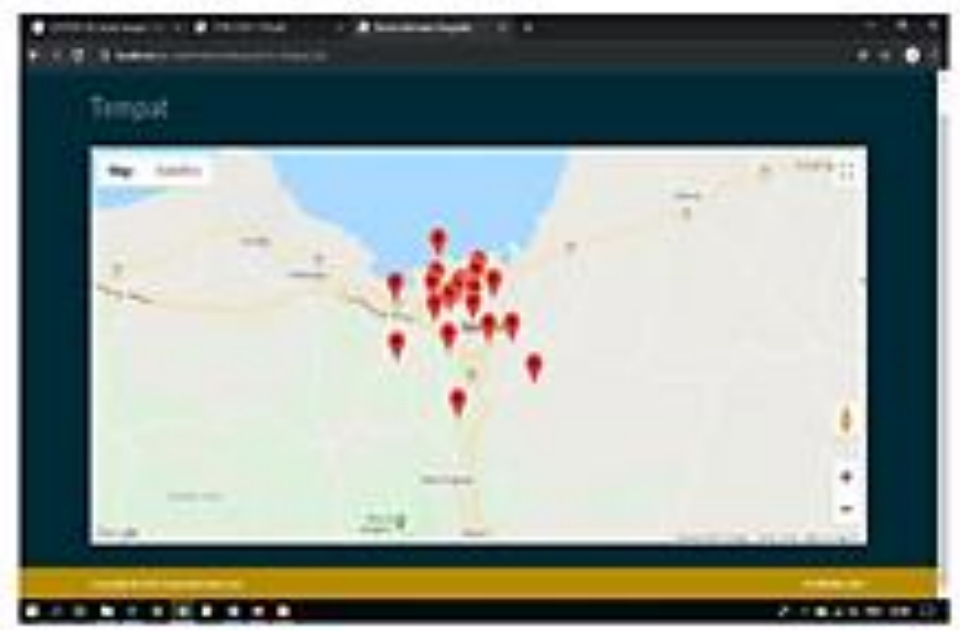

Gambar 1. Komponen SIG

b. Algoritma Dijkstra

Algoritma Dijkstra adalah sebuah algoritma greedy yang dipakai dalam memecahkan permasalahan jarak terpendek untuk sebuah graf berarah dengan bobot-bobot sisi (edge) yang bernilai tak negatif [11]. Ide dasar algoritma Dijkstra sendiri ialah pencarian nilai cost yang terdekat dengan tujuan yang berfungsi pada sebuah graf berbobot, sehingga dapat membantu memberikan pilihan jalur. Pada Algoritma Dijkstra, node digunakan karena Algorima Dijkstra menggunakan graph berarah untuk penentuan rute lintasan terpendek. Algoritma ini bertujuan untuk menemukan jalur terpendek berdasarkan bobot terkecil dari satu titik ke titik lainnya. Misalkan titik 
JAST : Journal of Applied Science and Technology

Volume. 02 Number. 01, January 2022

ISSN : 2775-4022

http://jurnal.unissula.ac.id/index.php/JAST

mengambarkan obyek dan garis menggambarkan jalan, maka Algoritma Dijkstra melakukan kalkulasi terhadap semua kemungkinan bobot terkecil dari setiap titik.

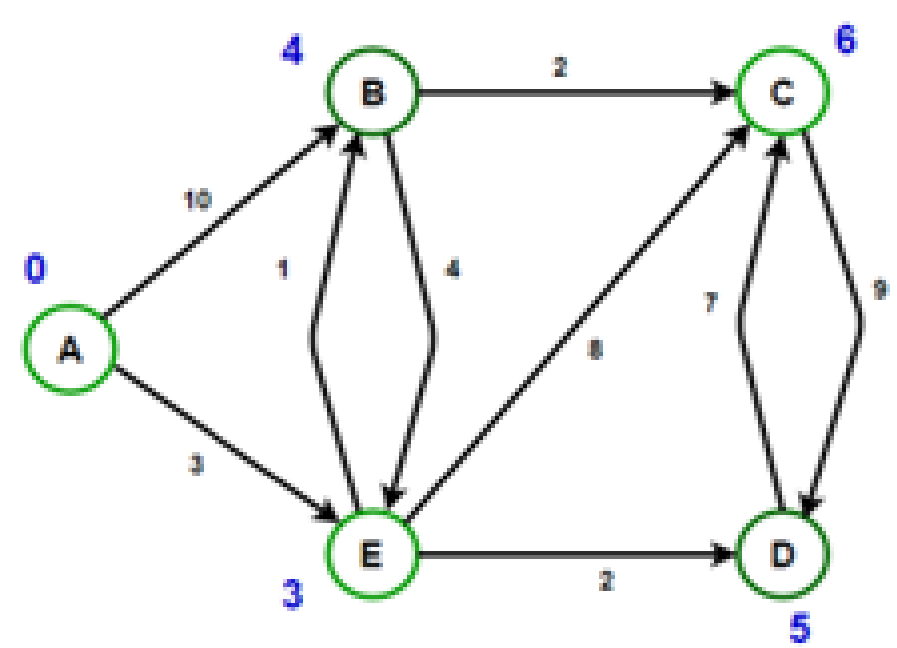

Gambar 2. Graph dijkstra

\section{RESEARCH METHOD}

Penelitian ini adalah penelitian pengembangan dari penelitian yang sebelumnya pernah dilakukan oleh Saputra (2011) [12]. Maka dari penelitian yang sudah ada dikembangkan di lokasi obyek wisata yang berbeda dengan penerapan metode yang berbeda

Adapun penelitian ini dilakukan di Lokasi Obyek wisata di Kota Semarang. Nantinya lokasi Obyek wisata tersebut akan di kelompokkan berdasarkan jenis wisata seperti wisata religi, wisata lingkungan, wisata budaya, wisata air, wisata pendidikan.

Data / bahan yang dipakai selama penelitian ini yaitu sebagai berikut :

a. Data spasial

Data Spasial merupakan data dalam bentuk grafik yang memperlihatkan tempat-tempat / lokasi di Kota Semarang. Data Spasial dilambangkan dengan garis, polygon \& titik. Seperti titik longitude \& latitude.

b. Data Atribut

Data Atribut merupakan data yang digunakan untuk deskripsi / memberi penjelasan dari tiap-tiap objek di Kota Semarang. Seperti: nama obyek wisata, data nama jalan, panjang jalan, lokasi titik awal \& akhir jalan.

Pada tahapan penelitian yang akan dilakukan yaitu studi literatur untuk referensi dalam pembuatan project ataupun sistem informasi. Selanjutnya, setelah mendapatkan literatur yang cukup, akan dibuat sebuah database yang nantinya digunakan sebagai pedoman sekaligus informasi dalam pembuatan project berupa web. Selanjutnya pembuatan project, pembuatan project nantinya berupa web yang mudah dipahami oleh penguna, agar mampu memberikan manfaat. Pembuatan web dengan implementasi algoritma dijkstra didalamnya, digunakan sebagai pencarian rute optimum menuju antar lokasi wisata. Tahap penelitian dapat dilihat pada Gambar 3. 


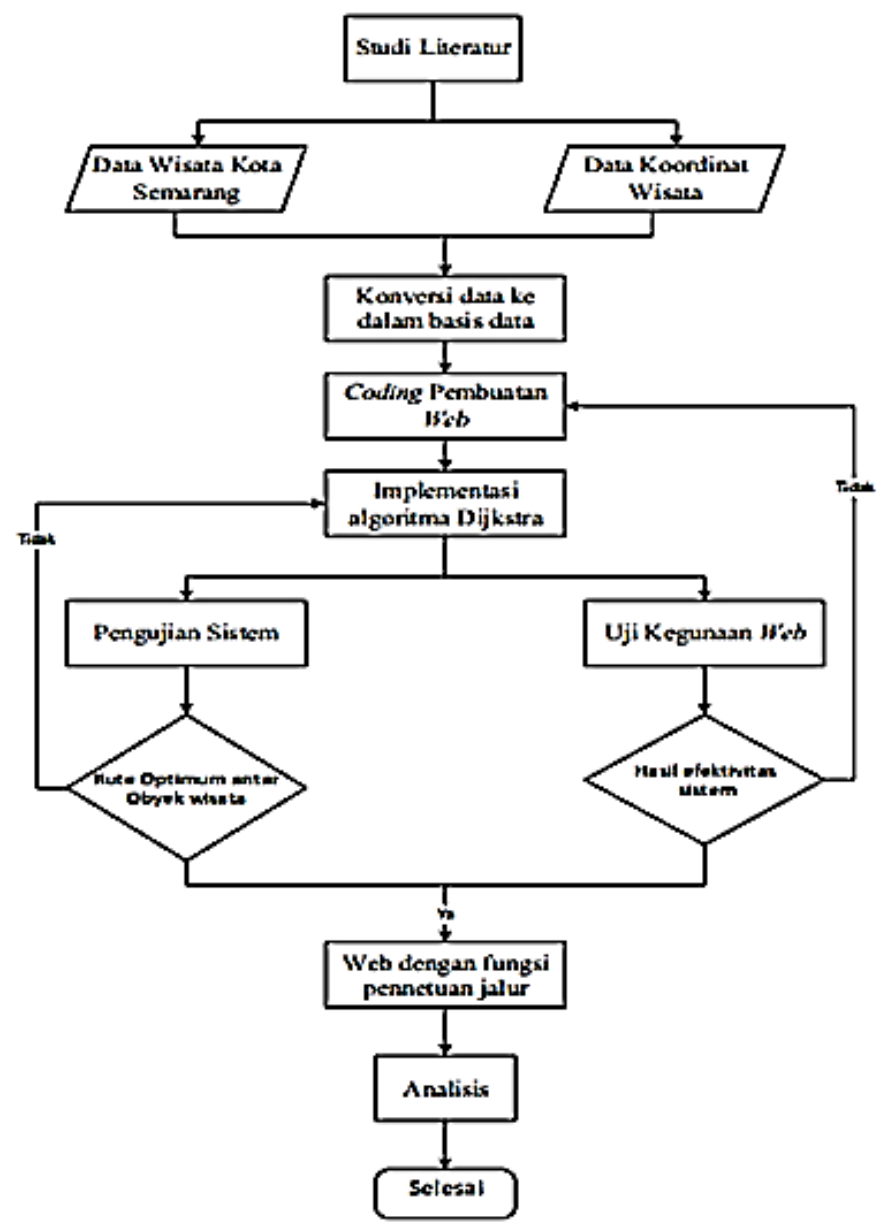

Gambar 3. Tahapan Penelitian

Adapun tahapan tahapan dalam pengembangan Sistem informasi geografis ini adalah menggunakan model Waterfall, yaitu dengan langkah-langkah berikut ini:

a. Analisis Kebutuhan

Pada langkah ini melakukan proses pengumpulan informasi yang diperlukan pengguna \& dideskripsikan mendetail yang kemudian digunakan sebagai standar kebutuhan dari sistem. Pada tahapan ini peneliti mencari informasi obyek wisata berdasarkan berita update di internet seperti seputarsemarang.com, anekawisata, idntimes, traveloka dan studi di lapangan. Kemudian pada langkah ini dilaksanakan juga analisa kebutuhan analisis dari sistem yang akan digunakan. Tahapan perancangan ini didefinisikan kebutuhan-kebutuhan sistem, baik Hardware dan Software.

b. Desain Sistem

Langkah perancangan desain sistem ini melakukan proses mendesain dari sistem yang akan dibuat, dengan menggunakan teknik / metode yang sudah direncanakan. Peneliti merancang sistem yang akan digunakan dengan menggunakan Unified Modeling Language (UML) untuk merancang sistem yang dibuat. Nantinya perancangan akan diilustrasikan dengan berbagai simbol untuk menyelesaikan bug pada program.

c. Implementasi

Langkah ini melakukan pembuatan sistem / software yang berdasarkan dari kebutuhan dari sistem pada langkah sebelumnya. Pada tahapan ini juga sistem di bangun dengan struktur yang telah didesain pada tahapan sebelumnya. Peneliti membuat software sistem informasi dengan mengunakan bahasa pemrograman PHP dan javascript dengan editor sublime text. Serta dengan menggunakan algoritma dijkstra untuk memecahkan masalah menentukan rute optimum.

d. Pengujian Sistem

Pada langkah ini Software yang dirancang akan diintegrasikan dengan semua sistem yang telah dibuat, sehingga hasilnya akan sesuai atau tidak. Lalu dilaksanakan proses testing dari software yang dibuat. Proses tersebut akan 
JAST : Journal of Applied Science and Technology

Volume. 02 Number. 01, January 2022

ISSN : 2775-4022

http://jurnal.unissula.ac.id/index.php/JAST

dilakukan di kehidupan nyata. Pengujian program atau testing program meliputi user acceptance test dan black box untuk mendapatkan informasi apakah software tersebut bisa digunakan / tidak.

e. Perawatan

Pada langkah ini melaksanakan maintenance dari software yang dibuat. Pada langkah ini juga perlu adanya perbaikan apabila muncuk kesalahan yang belum didapatkan pada langkah sebelumnya. Tetapi untuk penelitian kali ini, developer hanya sampai tahapan pegujian sistem / testing program saja.

\section{RESULT AND ANALYSIST}

Dari permasalahan diatas, maka akan dibuat sebuah tahapan rancangan untuk menyelesaikan masalaha yang dihadapi. Tahapan rancangan tersebut akan digunakan sebuah metode Waterfall untuk menyelesaikan permasalahan tersebut. Pada penggunaan Metode Waterfall meliputi beberapa tahapan seperti analisis kebutuhan sistem, desain software, tes dan implementasi, integrasi \& uji sistem, operasi \& perawatan. Untuk keperluan pengujian digunakan black box testing.

\subsection{Implementasi Desain dan Algoritma}

Implementasi merupakan gambaran tampilan layar user interface ketika pengguna membuka sebuah aplikasi atau pun tampilan yang ada di dalam komputer.

a. Desain tampil dashboard pengguna

Implementasi desain tampil dashboard pengguna akan menampilkan berita terkini tentang wisata Kota Semarang. Berikut tampilannya pada Gambar 4.

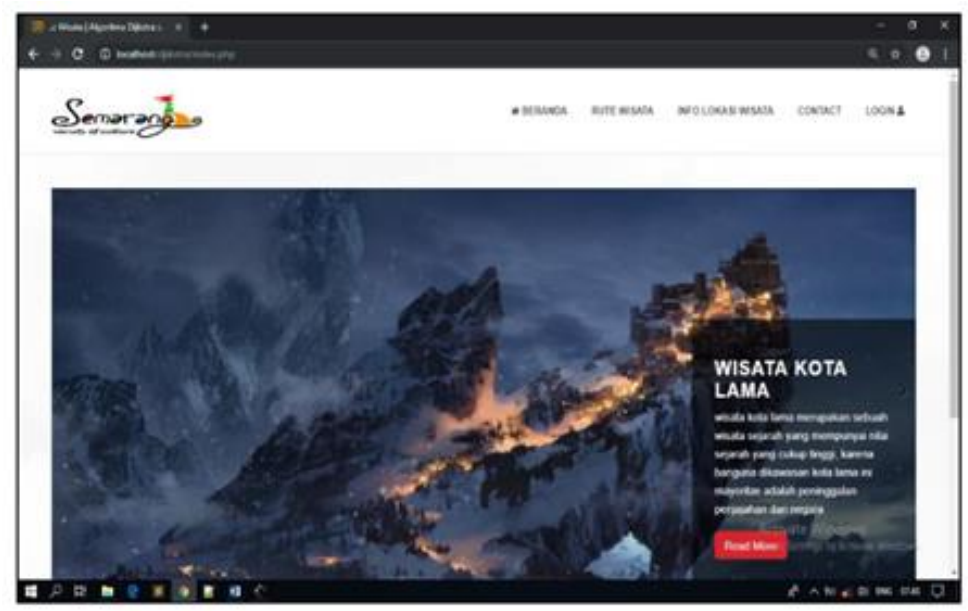

Gambar 4. Implementasi beranda user

b. Desain tampil info wisata

Implementasi desain tampil info wisata akan menampilkan jenis-jenis objek wisata yang berada di Kota Semarang beserta gambar wisata. Berikut tampilannya pada Gambar 5.

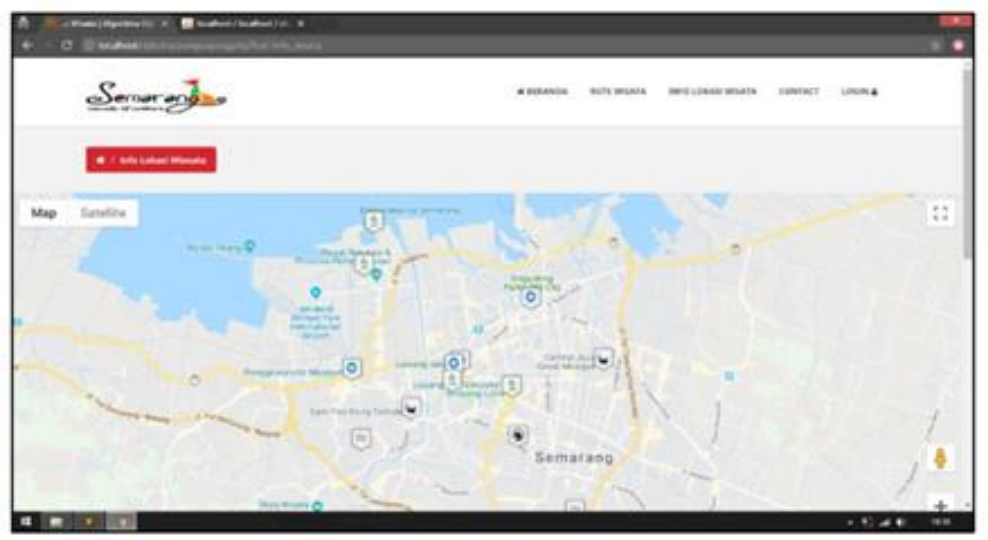

Gambar 5. Implementasi tampilan info wisata 


\subsection{Implementasi Algoritma Dijkstra dalam mencari rute optimum}

Algoritma dijkstra memakai prinsip greedy yaitu pada setiap tahapan yang dilalui dalam mendapatkan solusi yang optimal. Cara kerja dari algoritma tersebut yaitu membandingkan dari setiap nilai dari simpul pada satu level \& akan dibandingkan lagi pada rute yang baru. Dijkstra adalah algoritma yang popular terhadap pemecahan masalah optimasi mencari rute paling pendek pada lintasan. Penggunaan algoritma ini diterapkan untuk mencari rute optimum antar obyek wisata yang berada di Kota Semarang.

Algoritma Dijkstra dalam sistem informasi ini diakses untuk mendapatkan rute optimum menuju lokasi obyek wisata di Kota Semarang. Masukan dari rute ini yaitu node tujuan \& awal. Pada bagian menu untuk rute, user memasukkan titik tujuan \& awal dengan cara manual. Pada algoritma ini masukan tujuan \& awal yang berupa node diproses dengan melakukan perhitungan cost / nilai fungsi Dijkstra \& nilai heuristic pada banyak node termasuk di openset. Openset merupakan node-node yang bisa untuk dilewati, setelah memperhitungkan \& diperoleh node-node yang dapat untuk dilewati, lalu hasilnya diperlihatkan di peta sebagai path jalan yang digunakan dengan menggunakan Algoritma Dijsktra. Berikut implementasi mengenai algoritma dijkstra pada Gambar 6.

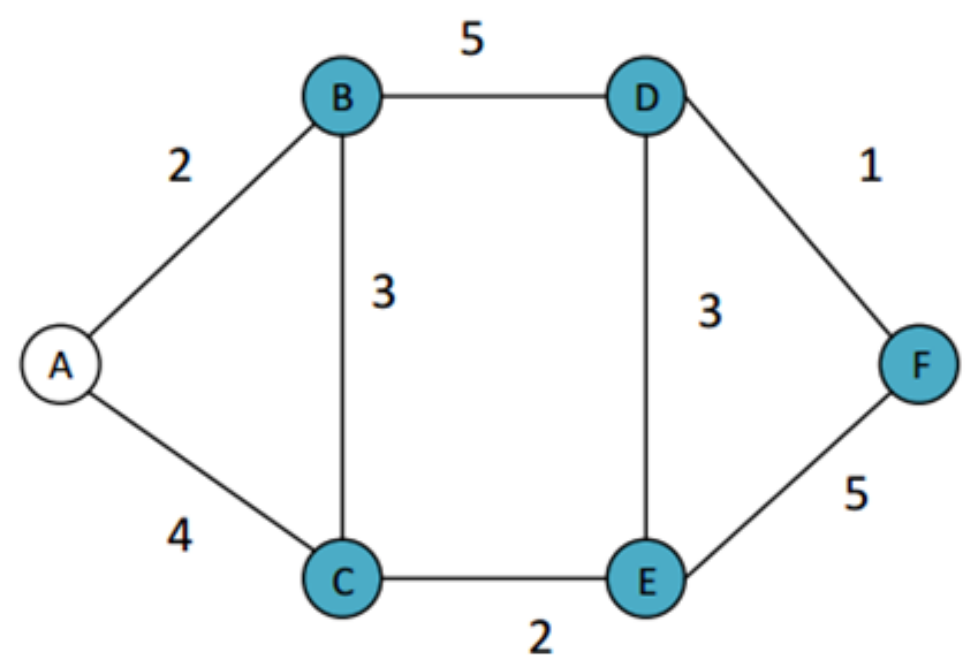

Gambar 6. Implementasi algoritma dijkstra

Penjelasan untuk gambar di atas yaitu :

1. Atur jarak untuk setiap titik ke titik berikutnya, kemudian beri nilai 1 pada node awal \& nilai tidak terhingga pada node lain (belum terisi).

2. Atur seluruh node yang belum terjamah \& atur node awal sebagai node keberangkatan.

3. Dari node keberangkatan, dilakukan pertimbangan dengan node sebelahnya yang belum terjamah \& menghitung jarak dari titik keberangkatan. Jika titik keberangkatan B ke A memiliki bobot jarak 2 \& dari C ke A berjarak 4, selanjutnya diambil bobot paling kecil adalah B ke A dengan jarak 2.

4. Sewaktu sudah memperhitungkan tiap jarak dari node tetangga, berikan tanda node yang sudah terjamah sebagai node terjamah. Node yang terjamah tidak dicek ulang, jarak yang disimpan yaitu jarak yang paling minimal bobotnya \& terakhir.

5. Atur node yang belum dijamah dengan jarak paling kecil sebagai node keberangkatan berikutnya \& meneruskan dengan kembali ke langkah 3. Berikut jarak optimal yang akan diperlihatkan rute dengan warna biru pada garis seperti di Gambar 7. 


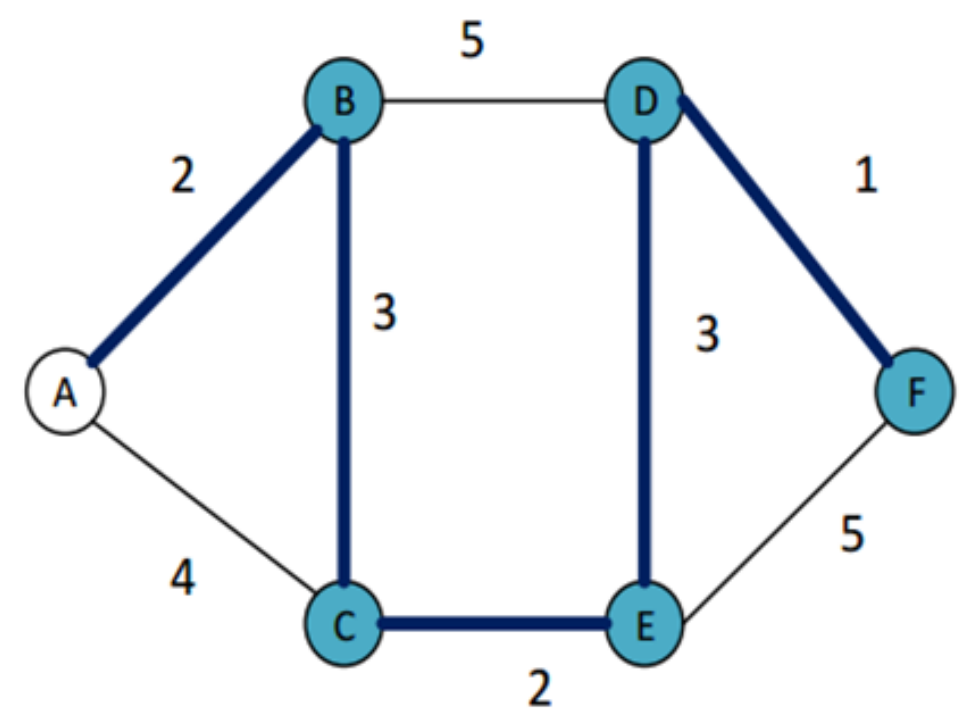

Gambar 7. Rute algoritma dijkstra

\subsection{Testing Program Dengan User Acceptance Test}

Testing program yang akan dilakukan yaitu user acceptance test (UAT). Berikut testing program yang dilakukan UAT untuk mengetahui sejauh mana sistem dapat digunakan dan berfungsi untuk pengguna. Pada pengujian UAT dilakukan kepada 7 peserta yang merupakan wisatawan, masyarakat umum serta Dinas Pariwisata Kota Semarang. Berikut hasil pengujian user acceptance test.

A. Hasil Pengujian Kuesioner Dari Segi Kemanfaatan

Tabel 1. Kesimpulan segi kemanfaatan

\begin{tabular}{|c|c|c|}
\hline No. & Pertanyaan & $\begin{array}{l}\text { Bobot } \\
\text { Penilaian }\end{array}$ \\
\hline 1 & $\begin{array}{l}\text { Apakah sistem membantu } \\
\text { pengguna dalam } \\
\text { menemukan obyek wisata di } \\
\text { Kota Semarang? }\end{array}$ & $100 \%$ \\
\hline 2 & $\begin{array}{l}\text { Apakah sistem mampu } \\
\text { memberi informasi mengenai } \\
\text { wisata di Kota Semarang? }\end{array}$ & $88,6 \%$ \\
\hline 3 & $\begin{array}{l}\text { Bagaimanakah keefektifan } \\
\text { sistem ini ketika digunakan } \\
\text { oleh wisatawan domestik } \\
\text { maupun mancanegara? }\end{array}$ & $80 \%$ \\
\hline \multicolumn{2}{|c|}{ Rata-rata } & $89,5 \%$ \\
\hline
\end{tabular}

Berdasarkan hasil persentase rata-rata nilai, maka dapat disimpulkan bahwa penilaian terhadap segi kemanfaatan adalah $89,5 \%$ dari $100 \%$ yang diharapkan, maka dapat dikategorikan sebagai sangat setuju.

B. Hasil Pengujian Kuesioner Dari Segi Penggunaan

Tabel 2. Kesimpulan segi penggunaan

\begin{tabular}{lll}
\hline No. & Pertanyaan & $\begin{array}{l}\text { Bobot } \\
\text { Penilaian }\end{array}$ \\
\hline 1 & $\begin{array}{l}\text { Apakah sistem ini mudah } \\
\text { dipakai? }\end{array}$ & $94,3 \%$ \\
\hline 2 & $\begin{array}{l}\text { Apakah sistem ini mudah } \\
\text { dipahami oleh pengguna? }\end{array}$ & $97,1 \%$ \\
\hline 3 & $\begin{array}{l}\text { Apakah sistem ini berisi } \\
\text { informasi yang dibutuhkan? }\end{array}$ & $82,9 \%$ \\
\hline
\end{tabular}




\begin{tabular}{lll}
\hline No. & Pertanyaan & $\begin{array}{l}\text { Bobot } \\
\text { Penilaian }\end{array}$ \\
\hline 4 & $\begin{array}{l}\text { Menurut anda, apakah sistem } \\
\text { ini sudah sesuai dengan } \\
\text { keperluan anda? }\end{array}$ & $82,9 \%$ \\
\hline Rata-rata & $89,3 \%$ \\
\hline
\end{tabular}

Berdasarkan hasil persentase rata-rata nilai, maka dapat disimpulkan bahwa penilaian terhadap segi penggunaan adalah $89,3 \%$ dari $100 \%$ yang diharapkan, maka dapat dikategorikan sebagai sangat setuju.

C. Hasil Pengujian Kuesioner Dari Segi Tampilan

Tabel 3. Kesimpulan segi tampilan

\begin{tabular}{llll}
\hline No. & Pertanyaan & $\begin{array}{l}\text { Bobot } \\
\text { Penilaian }\end{array}$ \\
\hline 1 & $\begin{array}{l}\text { Apakah sistem memiliki } \\
\text { tampilan yang menarik? }\end{array}$ & $91,4 \%$ \\
\hline 2 & $\begin{array}{l}\text { Apakah sistem memiliki } \\
\text { sistem yang jelas? }\end{array}$ & $88,6 \%$ \\
\hline 3 & $\begin{array}{l}\text { Apakah sistem memiliki } \\
\text { tampilan yang mudah } \\
\text { dipahami? }\end{array}$ & $88,6 \%$ \\
\hline Rata-rata & $89,5 \%$ \\
\hline
\end{tabular}

Berdasarkan hasil persentase rata-rata nilai, maka dapat disimpulkan bahwa penilaian terhadap segi tampilan adalah $89,5 \%$ dari $100 \%$ yang diharapkan, maka dapat dikategorikan sebagai sangat setuju.

D. Hasil Pengujian Kuesioner Dari Segi Akurasi

Tabel 4. Kesimpulan segi akurasi

\begin{tabular}{|c|c|c|}
\hline No. & Pertanyaan & $\begin{array}{l}\text { Bobot } \\
\text { Penilaian }\end{array}$ \\
\hline 1 & $\begin{array}{l}\text { Apakah sistem membantu } \\
\text { keperluan wisatawan? }\end{array}$ & $85,7 \%$ \\
\hline 2 & $\begin{array}{l}\text { Apakah informasi yang } \\
\text { diberikan sesuai dengan } \\
\text { kenyatan? }\end{array}$ & $97,1 \%$ \\
\hline 3 & $\begin{array}{l}\text { Apakah sistem menampilkan } \\
\text { informasi yang anda } \\
\text { inginkan? }\end{array}$ & $80 \%$ \\
\hline \multicolumn{2}{|c|}{ Rata-rata } & $87,6 \%$ \\
\hline
\end{tabular}

Berdasarkan hasil persentase rata-rata nilai, maka dapat disimpulkan bahwa penilaian terhadap segi akurasi adalah $87,6 \%$ dari $100 \%$ yang diharapkan, maka dapat dikategorikan sebagai sangat setuju.

\subsection{Testing Program Dengan White Box Test}

Pengujian whitebox testing adalah uji coba yang berdasarkan terhadap pengecekan pada rincian perancangan yang telah dibuat. Memakai kontrol struktur dari desain software dengan cara prosedural guna membagi testing menjadi beberapa skenario pengujian guna mendapatkan informasi apakah node pada independen path. Berikut Gambar 8 di bawah ini adalah Diagram alir script algoritma dijkstra: 


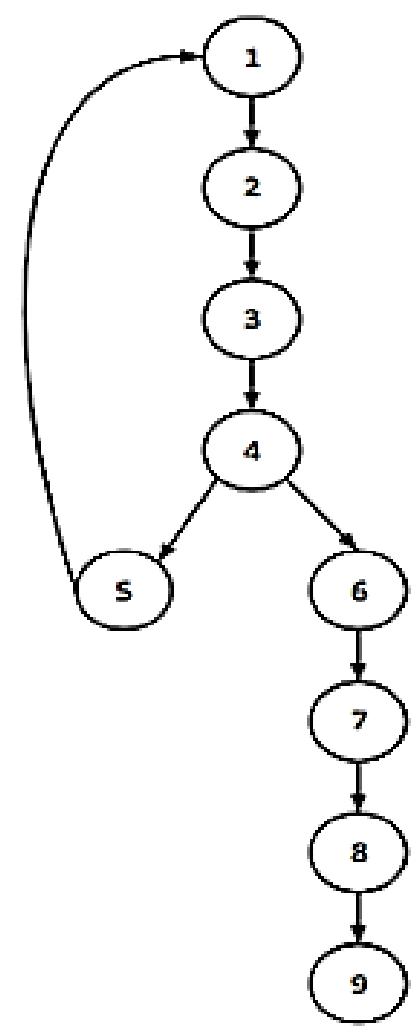

Gambar 8. Diagram alir script algoritma dijkstra

Menghitung Cyclomatic Complexity atau Kompleksitas siklomatis pengukuran kuantitatif dari grafik alir bisa didapatkan dengan perhitungan :

a. $\mathrm{V}(\mathrm{G})=\mathrm{E}-\mathrm{N}+2$

$\mathrm{V}(\mathrm{G})=9-9+2=2$

Keterangan :

E : Jumlah busur pada flowgraph

$\mathrm{N}$ : Jumlah simpul pada flowgraph

V (G) :Cyclomatic Complexity

b. $\mathrm{V}(\mathrm{G})=\mathrm{P}+1$

$\mathrm{P}=$ Jumlah predicate node pada grafik alir

Predicate node yaitu mendeskripsikan sebuah node yang mempunyai lebih / satu masukan \& lebih dari satu luaran. (pada kasus ini predicate node-nya adalah: 4) $\mathrm{V}(\mathrm{G})=1+1=2$. Dari hasil perhitungan tersebut, Cyclomatic Complexity yang didapatkan yaitu 2. Sebab nilainya tidak lebih dari 10 yang artinya masuk ke dalam algoritma yang memenuhi kriteria rekayasa perangkat lunak \& tidak kompleks.

Dari kompleksitas siklomatis \& gambar 6 di atas bisa ditentukan independen path. Terdapat 2 independen path yang diperoleh, Berikut di bawah ini :

Path $1: 1,2,3,4,1$

Path 2 : 1,2,3,4,5,6,7,8,9

Selanjutnya dilakukan pengujian value test yaitu sebagai pengujian pada setiap independen path.

Tabel 5. Value test Algoritma dijkstra

\begin{tabular}{cccc}
\hline Path & Input & Output & Ket \\
\hline Tidak & Diharuskan & Proses \\
melakukan & melakukan \\
inputan & telah \\
langsung & lokasi awal & terlewati \\
\hline
\end{tabular}


JAST : Journal of Applied Science and Technology

Volume. 02 Number. 01, January 2022

ISSN : 2775-4022

http://jurnal.unissula.ac.id/index.php/JAST

\begin{tabular}{|c|c|c|c|}
\hline Path & Input & Output & Ket \\
\hline & $\begin{array}{c}\text { mengklik } \\
\text { tombol } \\
\text { lihat }\end{array}$ & $\begin{array}{l}\text { dan lokasi } \\
\text { tujuan }\end{array}$ & \\
\hline $\begin{array}{c}1,2,3,4,5, \\
6,7,8,9\end{array}$ & $\begin{array}{l}\text { Melakukan } \\
\text { inputan } \\
\text { lokasi } \\
\text { awal dan } \\
\text { lokasi } \\
\text { tujuan }\end{array}$ & $\begin{array}{c}\text { Menampilkan } \\
\text { rute jalan } \\
\text { terdekat }\end{array}$ & $\begin{array}{l}\text { Proses } \\
\text { telah } \\
\text { terlewati }\end{array}$ \\
\hline
\end{tabular}

Berdasarkan hasil pengujian diatas pada Tabel 6 dapat diketahui hasil ketercapaian sebagai berikut :

$$
\begin{gathered}
\text { Tercapai }=\frac{2}{2} \times 100 \%=100 \% \\
\text { Gagal }=\frac{0}{2} \times 100 \%=0 \%
\end{gathered}
$$

\section{CONCLUSION}

Dalam penelitian ini dihasilkan sebuah Aplikasi SIG penentuan rute optimal lokasi daerah wisata di Kota Semarang dengan menggunakan Algoritma Dijkstra dan rute yang dilewati adalah dengan menggunakan kendaraan pribadi seperti motor, mobil dan travel. Dari hasil riset \& studi lapangan yang telah dilaksanakan, bisa ditarik kesimpulan dari pengujian UAT (segi kemanfaatan 89,5\%, segi penggunaan 89,3\%, segi tampilan 89,5\%, dan segi akurasi $87,6 \%$ ) artinya adalah sangat setuju. Dari hasil uji coba white box, Cyclomatic Complexity yang didapatkan yaitu 2. Sebab nilainya tidak lebih dari 10 yang artinya masuk ke dalam algoritma yang memenuhi kriteria rekayasa perangkat lunak \& tidak kompleks.

\section{REFERENCES}

[1] P. Blištan, L. Kovanič, and M. Kovaničová, "The Importance of Geographic Information Systems Education at Universities in the Process of Building a European Knowledge-based Society," in Procedia - Social and Behavioral Sciences, 2015, vol. 191, pp. 2458-2462.

[2] D. Ali et al., "A cost-effectiveness analysis of traditional and geographic information system-supported microplanning approaches for routine immunization program management in northern Nigeria," in Vaccine, 2020, vol. 38, pp. 14081415.

[3] S. L. Nimmagadda, T. Reiners, and L. C. Wood, "On modelling big data guided supply chains in knowledge-base geographic information systems," in Procedia Computer Science, 2019, vol. 159, pp. 1155-1164.

[4] I. Abbas, "Sistem Informasi Geografis Tata Letak Sekolah Luar Biasa Pada Dinas Pendidikan Kebudayan Pemuda Dan Olahraga Provinsi Gorontalo Berbasis Android," J. Inform. Upgris, vol. 4, no. 1, pp. 1-10, 2018.

[5] W. Wei, "Research on the Application of Geographic Information System in Tourism Management," in Procedia Environmental Sciences, 2012, vol. 12, pp. 1104-1109.

[6] G. D. Pradana, A. Suprayogi, and A. Sukmono, "Webgis Penentuan Jalur Hotel Terdekat Dari Kawasan Pariwisata Dengan Menggunakan Algoritma Dijkstra (Studi Kasus : Kota Semarang),” J. Geod. Undip, vol. 7, no. 2, pp. 97-106, 2018.

[7] B. Junanda, D. Kurniadi, and Y. Huda, "Pencarian Rute Terpendek Menggunakan Algoritma Dijkstra pada Sistem Informasi Geografis Pemetaan Stasius Pengisian Bahan Bakar Umum," J. Vokasional Tek. Elektron. Inform., vol. 4, no. 1, pp. 1-8, 2016.

[8] D. Ardana and R. Saputra, "Penerapan Algoritma Dijkstra pada Aplikasi Pencarian Rute Bus Trans Semarang," in Seminar Nasional Ilmu Komputer, 2016, SNIK, pp. 299-306.

[9] A. Fajri, E. P. Purwandari, and F. F. Coastera, "Implementasi Sistem Informasi Geografis untuk Pencarian Indekos dengan Jarak Terpendek menggunakan Metode Algoritma Dijkstra ( Studi Kasus : Kelurahan Kandang Limun dan Beringin Raya )," J. Rekursif, vol. 6, no. 1, pp. 69-79, 2018.

[10] J. E. Prasetyo, I. B. K. Widiartha, and M. A. Albar, "Sistem Informasi Geografis Pencarian Lokasi Wisata Kuliner Terdekat di Kota Mataram Berbasis Website,” J. Comput. Sci. Informatics Eng., vol. 1, no. 1, pp. 65-70, 2018.

[11] M. E. Kusuma and Y. Budisusanto, "Aplikasi Google Maps API dalam Pengembangan Sistem Informasi Geografis (SIG) Pariwisata Berbasis Web,” J. Geod. Geomatics, vol. 10, no. 02, pp. 129-136, 2015.

[12] R. Saputra, "Sistem Informasi Geografis Pencarian Rute Optimum Obyek Wisata Kota Yogyakarta dengan Algoritma Floyd-Warshall," J. Mat., vol. 14, no. 1, pp. 19-24, 2011. 